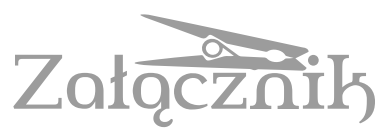

\title{
ROMANS Z ZEGARMISTRZEM
}

\author{
JAN ZIELIŃSKI
}

Wydział Nauk Humanistycznych UKSW

Faculty of Humanities, Cardinal Stefan Wyszyński University in Warsaw

zielinski@gmx.ch

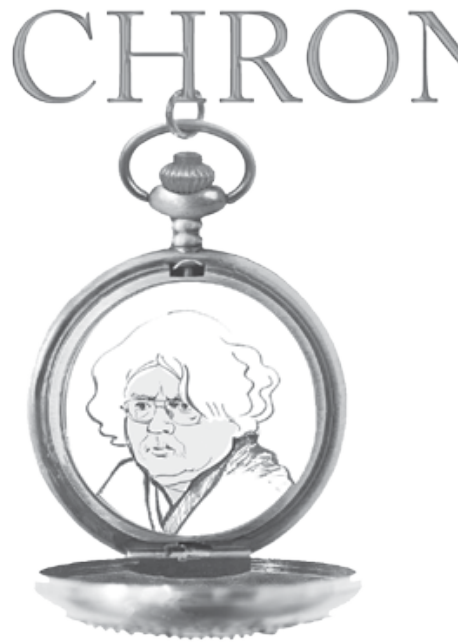

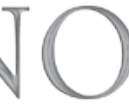
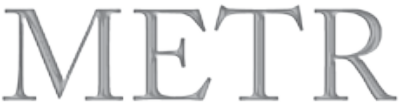

Autorska rubryka prof. UKSW i wykładowcy Uniwersytetu we Fryburgu Jana Zielińskiego. Stopniowa prezentacja wybranych wątków szeroko zakrojonego projektu, który ma przedstawić w układzie chronologicznym obecność motywu czasu

i zegara w kulturze polskiej (na tle międzynarodowym) od średniowiecza do XXI wieku. Punktem wyjścia jest przeważnie tekst literacki, ale odniesienia sięgają różnych dziedzin kultury (łącznie z kulturą materialną), historii, etnografii, filozofii. Poszczególne teksty, zbudowane z segmentów ułożonych na ogół chronologicznie, pokazują odrębne zagadnienie - czasem zaskakujące, czasem wręcz paradoksalne - w różnych jego aspektach.

Pod koniec maja roku 1651 doszło na Kresach do wypadku ukarania żony śmiercią za romans z zegarmistrzem. Mowa o drugiej żonie Bohdana Chmielnickiego, zwanej Heleną z Dzikich Pól (żonie nie całkiem zresztą prawowitej, jako że w chwili, gdy patriarcha jerozolimski Pajsiej udzielał ślubu jej i hetmanowi, żył jeszcze jej mąż, podstarości czehryński Daniel Czapliński). Wiadomość o sprawie dotarła do obozu królewskiego około 9 czerwca, pod tą datą zapisał ją w swym diariuszu Stanisław Oświęcim:

Pod tenże czas o Chmielnickiem i żenie jego przyszła wiadomość, że w pewnym zegarmistrzu, którego sobie od męża za ochmistrza danego miała, 
zakochawszy się, i zwyczajne z niem robieła niecnoty, i mężowi, gdzie mogła, szkodę czynieła. Długo to między niemi in secreto trwało, aż gdy Chmielnicki skarbów swoich pieniężnych (których curam tenże zegarmistrz miał) ruszając ex abscondito dla płacenia Tatarom, baryłki jednej pełnej czerwonych złotych domacać się nie mógł: rozumiał zrazu, że ją syn jego, idąc do Litwy z wojskiem, wziął z sobą. Lecz gdy za pisaniem swojem w tej materyej powziął od syna wiadomość, że jej nie tylko nie brał, ale i nie widział, kazał onego miłego swego podskarbiego tak długo tyranizować, aż poniewolnie musiał się przyznać nie tylko do ukradzenia tej baryłki, uczyniwszy i żonę jego complicem tej kradzieży, ale też i do niecnót i amorów z nią popełnianych. Za tą wiadomością nie długo deliberując Chmielnicki, obróciwszy miłość swoję, którą miał niezwyczajną do niej, w gniew, nie tak dla ukradzionego złota, jako dla zdradzanego łoża, kazał ich oboje, tak jako in actu bywali adulterii, nago związawszy, pospołu obiesić; co nam Król sam przy wieczerzy swojej z uciechą referował'

Albrycht Stanisław Radziwiłł w swych pamiętnikach pod datami 8 i 9 czerwca odnotowuje ujęcie jeńców kozackich, którzy donosili o przemieszczaniu się Chmielnickiego w kierunku Dubna. Na temat romansu „kresowej Heleny” z zegarmistrzem pisze w sumarycznym omówieniu poprzedniego miesiąca: „Ku końcowi tego m[iesią]ca od Chmielnickiego żona wzięta Czaplińskiemu, zmówiła się z zegarmistrzem, którego Chmielnicki był przyzwał ze Lwowa i z nim beczkę złota schowała, i podobno swobodniej z nim postępowała. Tymoszko, syn Chmielnickiego, doniósł to ojcu, który po uczynionej inkwizycyi, doszedł kradzieży i oboje na jednej szubienicy kazał obwiesić"2.

Tymoszko był synem hetmana z pierwszego małżeństwa, który starał się wówczas o rękę córki hospodara mołdawskiego, pięknej Rozandy Lupu; wedle niektórych autorów, jak psychiatra i historyk-amator Antoni J. Rolle, to on miał osobiście wykonać wyrok na swej macosze i jej kochanku: Chmielnicki „za przeniewierstwo i romans z zegarmistrzem kazał ją powiesić, ezgekucyą wykonał sam Tymoszko - pięknie więc wykształcony był ów

1 S. Oświęcim, Dyariusz 1643-1651, wyd. dr Wiktor Czermak, Kraków 1907, s. 298.

2 Albrecht Stanisław ks. Radziwiłł, Pamiętniki ... kanclerza w[ielkiego] litewskiego, wydane z rękopisu przez Edwarda Raczyńskiego, Poznań 1839, s. 437. 
przyszły mąż Lupułłówny”3. Tenże Rolle w opowiadaniu Pod Półksiężycem dośpiewał sobie wygląd i stan zegarmistrza: „Był to panicz rodem ze Lwowa, gładki, wdzięcznego lica, szlacheckich przywyknien'"4.

Trzeba dodać, że w tym czasie królowa, która towarzyszyła Janowi Kazimierzowi w kresowej wyprawie, nagle powróciła do Warszawy, a Jan Kazimierz przejął dziwny list, pisany do niej przez podkanclerzego koronnego Hieronima Radziejowskiego. Historyk Ludwik Kubala w opublikowanej w 1875 roku pracy o procesie Radziejowskiego połączy - niezbyt dokładnie w diariuszach Oświęcimia i Radziwiłła datowane - opowieści i napisze wręcz: „Przypadek zdarzył, że właśnie siedząc przy stole, opowiadał senatorom, jak żona Chmielnickiego z zegarmistrzem uciekła [!], kiedy mu przyniesiono list Radziejowskiego adresowany do królowej"5.

W Ogniem i mieczem Zaćwilichowski w rozmowie ze Skrzetuskim na temat konfliktu Chmielnickiego z Czaplińskim powiada o Helenie z Dzikich Pól: „Mówią przy tym, że żonę starostce bałamucił: starostka mu kochanicę odebrał i z nią się ożenił, a on mu ją za to później bałamucił, a to jest podobna rzecz, bo zwyczajnie... kobieta lekka"', ale wątek zegarmistrza autor Trylogii pominął. Podejmie go natomiast Franciszek Rawita-Gawroński w - opartym na drukowanych i rękopiśmiennych źródłach ukraińskich i polskich - opowiadaniu pod tytułem Weselna tragedia, zamieszczonym w roku 1908 w „Bibliotece Warszawskiej”. Sporo tu drastycznych szczególów, a trup ściele się gęsto: „Kręcił się tam jakiś "zegarmistrz ze Lwowa", człowiek młody, ale goły. [...] Czaplińska zdołała przekupić klucznika i wraz z zegarmistrzem jedną czy dwie beczki ze złotem zdobyła. [...] Zamierzali umknąć w świat. [...] Tymoszko [...] ojca zawiadomił o tym, co się stało. Rozkaz otrzymał krótki: powiesić wszystkich. Tymoszko wykonał polecenie. A tak mu było spieszno rozprawić się z macochą, że nawet szubienicy nie stawił, ale na szerokich wrotach ojcowskiego domu powiesił Imci panią Czaplińską samosiedm - razem ze wszystkimi towarzyszami miłości

3 Dr Antoni J. [Antoni J. Rolle], Zameczki podolskie na kresach multańskich, t. 2, Warszawa 1880, s. 95.

4 Dr Antoni J. [Antoni J. Rolle], Opowiadania historyczne. Pod Półksiężycem. Obrazek z przeszłości. Lwów 1875, s. 91.

5 L. Kubala, Szkice historyczne. Kraków 1896, s. 21.

${ }^{6}$ H. Sienkiewicz, Ogniem i mieczem, t. 1, Warszawa 1901, s. 19. 
i kradzieży”. Chmielnicki miał potem żałować pochopnego wyroku i pić na umór. Rawita-Gawroński dodaje jeszcze na temat zegarmistrza ze Lwowa, że nawet jego „nazwiska dzieje nie zachowały”.

Teodor Tomasz Jeż powieść $Z$ burzliwej chwili (1880-82) kończy wprawdzie sceną powieszenia młodej żony hetmana na bramie $\mathrm{z}$ rozkazu syna Chmielnickiego, ale wątek zegarmistrza pomija. Kobieca bohaterka powieści nosi imię Helena, tak samo jak ta, o którą wybuchła wojna trojańska i rzeczywiście, jest ona obiektem rywalizacji kilku mężczyzn. Bohdanowi Chmielnickiemu przypada tu rola sędziwego, starego Parysa. Jeż powiada: „W tym różnica - różnica, pociągająca za sobą rozchełznanie namiętności, posunięte do stopnia, do jakiego wznieść się nie mogli ani Trojanie, ani Grecy, którym do ręki oręż podawała miłość, ukwiecona urokiem młodości. Tam miłość, tu chuć za podnietę służyła". Znamienne to przeciwstawienie, pojawiające się w połowie drogi między Nietzschem (Narodziny tragedii, 1872; w późniejszym wydaniu opatrzone podtytułem Grecy i pesymizm) a Przybyszewskim, który w roku 1893 napisze Requiem aeternam ze słynnym zdaniem „Na początku była chuc"', i który w 1899 zacznie drukować w „Życiu” pierwsze fragmenty Synagogi szatana, jakby pamiętając z powieści Jeża słowa o tym, że panna Helena „niesiona przez miasto i prowadzona następnie przez ciemności, takim była przejęta uczuciem, jakby się znajdowała we władaniu szatana [...]”10.

Rawita-Gawroński do romansującego z Czaplińską zegarmistrza wraca w kilku szkicach o Tymoszce Chmielnickim, świadczących o swoistej negatywnej fascynacji tą postacią. W Ostatnim Chmielniczence pisze:

Romansowy zegarmistrz na dworze Czehryńskiego hetmana, Czaplińska zwykła nierządnica, przechodząca $\mathrm{z}$ rąk Podstarościego $\mathrm{w}$ ramiona kozackiego hetmana, syn jego Tymoszko, wieszający na wrotach ojcowskiego dworu własną macochę - na rozkaz ojca, wreszcie stary Bohdan, włóczący się z muzyką po „pasiekach”, gdzie go szukać muszą posłowie

7 F. Rawita-Gawroński, Weselna tragedia, t. 2, „Biblioteka Warszawska”, Warszawa 1908, s. 567-568.

8 T.T. Jeż, Z burzliwej chwili. Powieść historyczna, t. 3, Warszawa 1882, s. 269-270.

9 S. Przybyszewski, Requiem aeternam... trzecia księga Pentateuchu. Lwów 1904, s. 5.

10 T.T. Jeż, op. cit., s. 270-271. 
moskiewscy - wszystko to wytwarzało atmosferę chyba niezbyt wysokiej moralności. A jednak w takiej atmosferze wychował się Juraszko ${ }^{11}$.

Ponad sto lat później Jacek Komuda w powieści Bohun (2006) nawiązuje do romansu żony Chmielnickiego z zegarmistrzem ze Lwowa, a skoro ona ma być Heleną Dzikich Pól, jego czyni Kozakiem, ukraińskim odpowiednikiem Parysa spod Troi:

Nie wiadomo, czy przypominał on urodą sławetnego Parysa, pisali jednak o nim, iż fach miał całkiem rozumny - był zegarmistrzem, a przy okazji ochmistrzem hetmana. Helena nie tylko używała sobie z nim w łożnicy, gdy Chmiel wojował z Lachami, ale nawet ukradła z piwnic pod Subotowem baryłkę z czerwonymi złotymi. Kiedy Chmielnicki nie mógł się jej doliczyć, kazał, jak podaje Stanisław Oświęcim, tak długo „tyranizować” ochmistrza, aż pomieniony zegarmistrz przyznał się nie tylko do kradzieży, ale i romansu z Heleną. Dowiedziawszy się o tak podstępnej zdradzie, Chmielnicki nakazał rozebrać kochanków do naga, ułożyć w miłosnej pozycji, związać i razem powiesić12.

Intrygująca poetka olsztyńska Alicja Bykowska-Salczyńska w wierszu Pomnik Bohdana Chmielnickiego w Kowlu z tomu Cno (2016) daje taki obraz:

Na wieszakach kołyszą się

czerwona suknia i czarny garnitur

ciało w ciało nicość w nicość nago powieszeni

piękna Helena z Dzikich pól

niewierna żona $\mathrm{z}$ kochankiem in actu

Narody przemijają, miłość - nigdy

Chmielnicki musi na to patrzeć

Łuszczy się ${ }^{13}$.

Zadziwiająca jest trwałość pewnych motywów. Nie ma tu przecież wprost mowy o zegarmistrzowskim zawodzie kochanka żony Chmielnickiego, ale sentencja „Narody przemijają, miłość - nigdy” mówi o przemijaniu (bądź nieprzemijaniu) i ma zwięzłość gnomy na zegarze słonecznym.

${ }_{11}$ F. Rawita-Gawroński, Ostatni Chmielniczenko. (Zarys monograficzny). 1640-1679, Poznań 1919, s. 145.

12 J. Komuda, Od Autora, [w:] idem, Bohun, Lublin 2006, s. 320.

13 A. Bykowska-Salczyńska, Cno, Olsztyn 2016, s. 44. 